\title{
JC Polyomavirus and Transplantation: Implications for Virus Reactivation after Immunosuppression in Transplant Patients and the Occurrence of PML Disease
}

\author{
James E. K. Hildreth ${ }^{1,2,3}$ and Donald J. Alcendor ${ }^{1,3, *}$ \\ 1 Center for AIDS Health Disparities Research, Department of Microbiology and Immunology, School of \\ Medicine, Meharry Medical College, 1005 Dr. D.B. Todd Jr. Blvd., Nashville, TN 37208, USA; \\ jhildreth@mmc.edu \\ 2 Department of Internal Medicine, School of Medicine, Meharry Medical College, 1005 Dr. D.B. Todd Jr. Blvd., \\ Nashville, TN 37208, USA \\ 3 Center for AIDS Health Disparities Research, Immunology, and Physiology, Department of Microbiology, \\ School of Medicine, Meharry Medical College, 1005 Dr. D.B. Todd Jr. Blvd., Nashville, TN 37208, USA \\ * Correspondence: dalcendor@mmc.edu
}

Citation: Hildreth, J.E.K.; Alcendor, D.J. JC Polyomavirus and

Transplantation: Implications for

Virus Reactivation after

Immunosuppression in Transplant Patients and the Occurrence of PML Disease. Transplantology 2021, 2,

37-48. https://doi.org/10.3390/ transplantology2010004

Academic Editor: Nassim Kamar

Received: 15 December 2020

Accepted: 29 January 2021

Published: 2 February 2021

Publisher's Note: MDPI stays neutral with regard to jurisdictional claims in published maps and institutional affiliations.

Copyright: (c) 2021 by the authors. Licensee MDPI, Basel, Switzerland. This article is an open access article distributed under the terms and conditions of the Creative Commons Attribution (CC BY) license (https:// creativecommons.org/licenses/by/ $4.0 /)$.

\begin{abstract}
The JC polyomavirus (JCPyV/JCV) is a member of the Polyomaviridae family and is ubiquitious in the general population, infecting $50-80 \%$ of individuals globally. A primary infection with JCV usally results in an asymptomatic, persistent infection that establishes latency in the renourinary tract. Reactivation from latency via iatrogenic immununosuppression for allograft transplantation may result in organ pathology and a potential life-threatening neuropathological disease in the form of progressive multifocal leukoencephalopathy (PML). Currently, no treatment exists for PML, a rare complication that occurs after transplantation, with an incidence of 1.24 per 1000 persons a year among solid organ transplant patients. PML is also observed in HIV patients who are immununosuppressed and are not receiving antiretroviral therapy, as well as individuals treated with biologics to suppress chronic inflammatory responses due to multiple sclerosis, Crohn's disease, non-Hodgkin's lymphoma, rheumatoid arthritis, and other autoimmune-mediated hematological disorders. Here, we describe the proposed mechanisms of JCV reactivation as it relates to iatrogenic immunosuppression for graft survival and the treatment of proinflammatory disease, such as biologics, proposed trafficking of JCV from the renourinary tract, JCV central nervous system dissemination and the pathology of PML in immunosuppressed patients, and potential novel therapeutics for PML disease.
\end{abstract}

Keywords: JC polyomavirus; transplantation; progressive multifocal leukoencephalopathy; immunosuppression; neuropathology

\section{Introduction}

The JC polyomavirus (JCPyV/JCV) is a member of the Polyomaviridae family, genus Orthopolyomavirus, which also includes the BK polyomavirus (BKPyV/BKV) [1-3]. Both viruses were isolated from patients with the initial JC and BK polyomaviruses, respectively $[1,2]$. JCV is thought to be transmitted by inhylation and infects $50-80 \%$ of the global population [4,5], with $10-30 \%$ of the world population shedding JCV in their urine [6]. $\mathrm{JCV}$ produces an asymptomatic, persistent infection primarily in the renourinary tract, reactivating only when the immune system is compromised. The reactivation of latent JCV in the brain of immune-compromised individuals may result in a lytic infection of oligodendrocytes, glial cells, and astrocytes [7-11]. The demyelination of oligodendrocytes induced by JCV lytic replication may lead to progressive multifocal leukoencephalopathy (PML). PML is a frequently fatal demyelinating infectious disease of the brain caused by neuropathogenic prototypes of JCV and is accompanied by progressive neurological deficits and death [11-15]. The spectrum of neurological presentations includes ataxia, hemiparesis, hemianopia, cognitive impairment, limb ataxia, gait disorder, and aphasia. 
The commonly involved areas include the subcortical white matter, periventricular areas, and cerebellar peduncles. PML is rare, with an incidence of $<0.3 / 100,000$ persons a year among the general population [16]. However, the incidence of PML HIV / AIDS patients without antiretroviral therapy is 2.4 per 1000 persons a year [17]. PML occurs in 3-5\% of HIV-infected individuals with an uncontrolled disease, but HIV therapy has been shown to improve clinical outcomes $[6,10,11,18]$. This is a significantly higher incidence when compared to patients with other means of immunomodulation therapy. The clinical presentations of PML disease include motor weakness, speech abnormalities, cognitive deficits, headache, visual fields deficits, ataxia, aphasia, cranial nerve deficits, and seizures $[8,10,19]$.

Currently, no specific treatment exists for JCV-induced PML. This represents an urgent unmet medical need for efficacious therapeutics for JCV-induced PML in immunocompromised patients. In addition, no suitable animal model for PML exists due to the failure of JCV to productively replicate in nonhuman hosts cells [20,21]. Here, we examine the role of iatrogenic immunosuppression on JCV reaction and the neuropathology that may result post-reactivation.

\section{JCPyV Biology}

JCV, along with BKV, identified in 1971, were the first two polyomaviruses associated with human, but not oncogenic, disease [2,3]. To date, 13 different polyomaviruses exist that may infect humans, and this number likely will rise due to novel methodologies used in virus discovery [22]. Five out of the 13 human polyomaviruses have been associated with clinical disease, including JCV, BKV, Trichodysplasia spinulosa polyomavirus, human polyomavirus 7, and Merkel cell polyomavirus [22]. JCV is a small nonenveloped, doublestranded, circular DNA virus with a five-kilobase genome associated with cellular histones, forming a viral mini-chromosome that replicates in the nucleus of permissive cells. Erickson et al. showed that the JCV recruits and modulates the host DNA damage response to replicate its genome [23]. JCV encodes six proteins, the large $\mathrm{T}$ and small $\mathrm{t}$ antigens, which have oncogenic properties, three capsid proteins (VP1-3), and the agnoprotein [24]. Currently, it is unknown whether the transmissible form of the virus is archetypal (found in the kidney, urine, and sewage, such as the CY strain of JCV); prototypical (found in the brain and is associated with PML, such as the Mad-1 strain of JCV); or both. These two types of JCV viruses differ only within their noncoding regulatory region (NCRR). The prototypical JCV-PML types isolated from the cerebrospinal fluid (CSF) and brain tissues from PML patients have rearrangements, including duplications, tandem repeats, and insertions and deletions in the NCRR region. Evidence of JCV persistence has been found in renal tissue, bone marrow, and brain tissue. This state of persistence appears as episomal circular DNA that is nonreplicating, with no viral gene transcription. Evidence of genomic DNA in normal brain tissue has been observed [25]. The asymptomatic shedding of JCV occurs in the adult human population at a level of 50,000 copies $/ \mathrm{mL}$ of urine. It has been demonstrated by Coleman et al. that pregnant women in their second and third trimesters may shed JCV asymptomatically at a rate of 3.2\% [26]. The seropositivity rates for JCV are found in the range from $39 \%$ to $81 \%$ and to steadily rise as an individual reaches adulthood, having more sustained viral titers when compared to BKV [5,27]. Primary infections are thought to occur in childhood via the upper respiratory tract through inhalation and, also, via the gastrointestinal route due to contaminated food or water (Figure 1). These findings are supported by the presence of JCV in the tonsils and intestinal cells, respectively [28-30]. In addition, JCV is known to infect B cells in the peripheral circulation, adding to the complexity of viral transmission (Figure 1). JCV infection is endemic and ubiquitous, and transmission occurs in childhood by the feco-oral, urinooral, and respiratory routes. The virus will remain latent in the bone marrow, kidneys, tonsils, lymphoid tissues, and/or the brain throughout the life of an infected individual (Figure 1). Over time, if an individual becomes immunocompromised, JCV may reactivate from latency and cause a life-threatening clinical disease, most notably in the form of PML (Figure 1). 


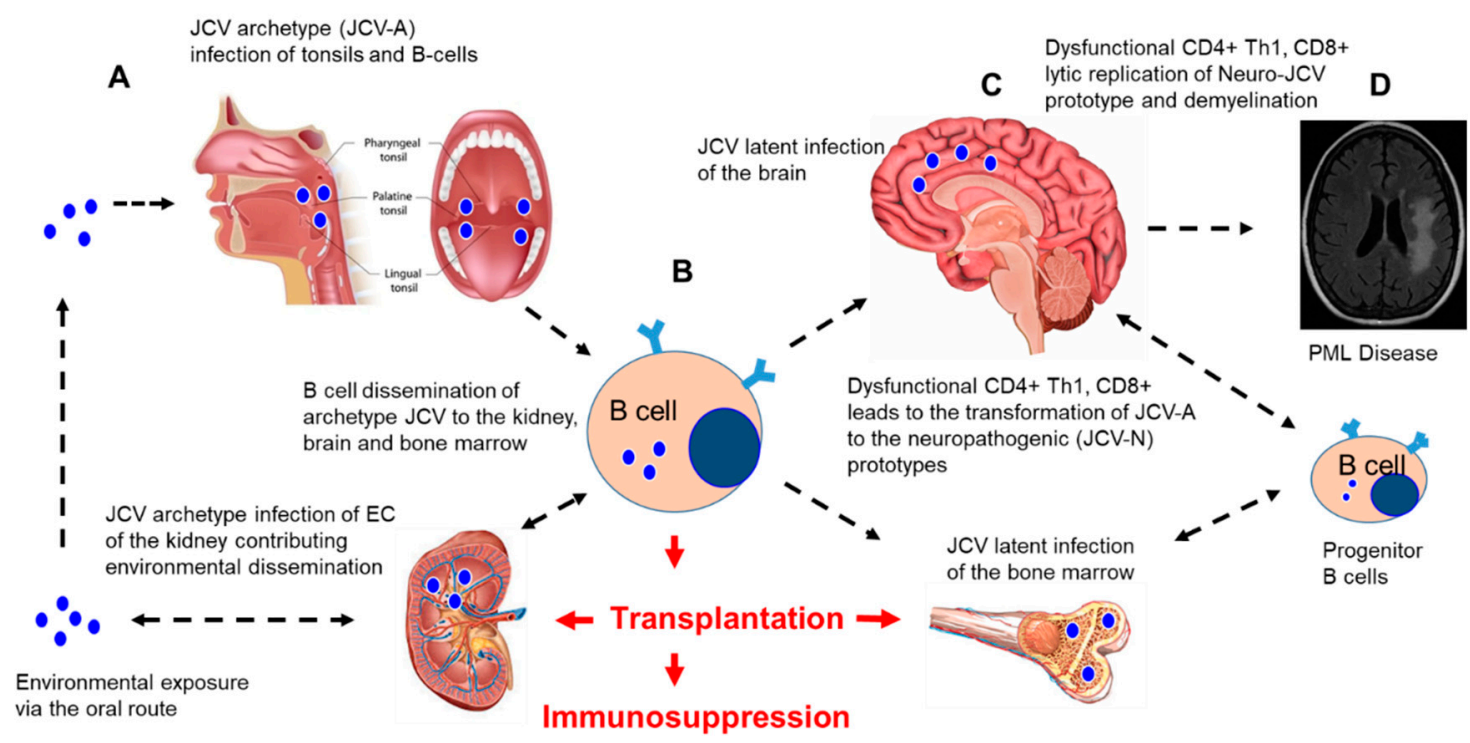

Figure 1. JC polyomavirus (JCV) infection and dissemination from environmental exposure to a latent infection and implications for immunosuppression after transplantation. A hypothetical model of JCV infection, latency, and reactivation in the brain after iatrogenic immunosuppression in transplant patients. (A) Environmental exposure to JCV occurs via the oral route with the initial infection and replication of the non-neuropathogenic archetype (JCV-A) in the tonsils and B cells. (B) JCV-A infection of B cells leads to the dissemination of JCV-A to the kidney, bone marrow, and brain, where latent infections are established. (C) Immunosuppression for a solid organ or stem cell transplantation results in the suppression of immune surveillance, resulting in the impairment of CD4+, Th1, and CD8+ responses and the infection of B cell progenitors that may lead to transformations (mutations in the noncoding regulatory region (NCRR) and VP-1 capsid protein) of the JCV-A prototype virus to the neuropathogenic prototype virus (JCV-N) that induces lytic replication in the oligodendrocytes and demyelination. (D) Uncontrolled multifocal lytic replication of JCV-N in the brain, followed by progressive demyelination, resulting in progressive multifocal leukoencephalopathy (PML), as diagnosed by brain imaging. Figure 1A was modified from a figure provided by Teach-Me-Anatomy. Figure 1C was modified from an image developed by Tim Taylor from Inner Body Research, Brain: Anatomy Mastery Course. Figure 1D was obtained and modified from Infectious Disease Advisor: JC polyomaviruses: Progressive Multifocal Leukoencephalopathy (Clinical Condition). The bone marrow image was obtained and modified from Health Visions, bloodless bone marrow transplants Narayana Health City. We acknowledge the National Kidney foundation for the image of the human kidney (unpublished data) EC: endothelial cells.

\section{JCV Reactivation from Latency and CNS Dissemination after Immunosuppression}

JCV is the only human neurotropic polyomavirus that reactivates in the brain under conditions of immunosuppression to cause a severe life-threatening clinical disease. JCV latency is defined as a subclinical, chronic, persistent infection, where JCV DNA, not proteins, may be detected at the site of latent reservoirs. This occurs after immune control of the viremic phase. Polyomavirus-associated nephropathy typically occurs due to BKV, but on occasion, it occurs due to the reactivation of JCV, which occurs almost exclusively in immunosuppressed individuals. JCV rarely causes kidney disease, whereas BKV is a known cause of viral nephropathy [31]. There is a higher incidence of BKV reactivation than JCV reactivation in renal transplant patients [32]. BKV reactivation, as demonstrated clinically by active viruria, which occurs in $23-57 \%$ of renal allograft recipients, and BKVassociated nephropathy in as many as $8 \%$ of renal allograft recipients. In a study by Lopez et al., they estimated the incidence of JCV viruria to be around 25\% [33]. Wiegley et al. observed that, unlike BKV infection, which occurs early post-transplantation, JCV nephropathy occurs at both early and late times after renal transplantation, and that differential diagnosis for BKV may be problematic [34].

JCV often establishes latency in the kidneys, where it displays a stable archetypal noncoding control region (NCCR) in the noncoding region of its genome (Figure 1). The 
rearrangement of gene sequences in the NCCR of JCV DNA is essential for the reactivation of these latent forms that are associated with PML [35]. The primary sites of viral latency after transmission include the kidney, bone marrow, and B lymphocytes (Figure 1) [36-38]. The virus enters the brain via circulation by penetration of the blood-brain barrier (BBB) to establish a nonproductive/low level of infection in the glial cells [39]. No clear understanding of JCV reactivation has been established; however, it has been suggested that a high incidence of infection and the rare incidence of PML imply that many host cell factors are involved in suppressing JCV reactivation [40] (Figure 1). The immune system plays a key role in controlling JCV reactivation from latency, leading to active viral replication and the development of PML (Figure 1). It has been proposed that transcription factorbinding sites located in the NCRR induce cytokine signaling transduction pathways in the binding factors, such as NF-kB, AP-1, Egr-1, and C/EBP $\beta$, which serve to jumpstart viral transcription and DNA replication in response to extracellular cytokines, with primary lesions developing at local sites in the brain parenchyma [41-45]. Further progression of the lesions occurs in the absence of CNS immunosurveillance during immunosuppression. In HIV-infected patients who develop PML, it is proposed that the HIV Tat protein has a role due to its ability to enhance JCV transcription and viral replication $[46,47]$. B cells are implicated in harboring and trafficking latent prototype PML-JCV in the CNS [48]. The exact viral and host cell factors that contribute to JCV reactivation are currently unknown; however, the outcome appears to depend on the nature of the immunosuppression and patient-specific factors that predispose individuals to JCV reactivation in the CNS and the development of PML disease.

\section{PML in Immunosuppressed Patients}

\subsection{Transplant Patients}

PML may be problematic in iatrogenic immunocompromised patients and is a rare complication of solid organ transplantation, mainly due to the virus reactivation, with an incidence of 1.24 per 1000 persons a year [49] (Figure 2). However, PML has a mortality rate of $84 \%$ and a median survival rate following symptom onset of 6.4 months in solid organs vs. 19.5 months in bone marrow recipients [49].

PML may often present as neurological symptoms, along with abnormal magnetic resonance imaging (MRI) findings during immune recovery for allograft transplantations. This may be observed with immunosuppressants, such as mycophenolate mofetil (MMF) and tacrolimus. Reduction in patients' immunosuppressive regimens has resulted in the development of immune reconstitution inflammatory syndrome (IRIS), an immune-induced inflammatory response to JCV replication in the brain parenchyma that results in serious neuronal damage [50]. A case report by Bennett et al. found PML that developed in a 67-year-old male who received an autologous stem cell transplant (ASCT) for multiple myeloma (Figure 2). The patient received induction treatment with four cycles of bortezomib, thalidomide, and dexamethasone [51]. Computerized tomography scanning showed evidence of PML, and an MRI of the brain showed numerous hyperintense T2 lesions within the subcortical white matter of both cerebral hemispheres, indicative of PML disease. The patient's CSF was positive for JCV, with 830,000 copies/mL [51]. PML disease is a rare complication of ASCT for multiple myeloma, with only 11 cases reported in the literature, and is highly fatal. Lippa et al. reported PML presenting with acute sensorineural hearing loss in an intestinal transplant recipient (Figure 2). The study involved a 20-year-old male that clinically presented with rapidly progressive sensorineural hearing loss 3.5 years after intestinal transplant surgery [52]. The MRI of the brain was consistent with inflammation and/or demyelination. The patient was found to be JCV-positive after lumbar puncture. The patient continually deteriorated after the withdrawal of prior immunosuppression therapy and subsequent treatment with mirtazapine, maraviroc, and steroids. The patient died of PML five months after his initial clinical presentation [52]. Ahmadinejad et al. described PML that developed in a 41-year-old female after liver transplantation [53]. The patient required a liver transplantation due to liver failure resulting 
from autoimmune hepatitis [53]. She was admitted with a stroke attack, resulting in a right hemiplegia two months post-transplantation, during which time, she developed dysarthria and left central facial paresis. An MRI showed abnormal multifocal lesions, with a high T2-weighted fluid-attenuated inversion-recovery (T2-FLAIR) signal in the deep subcortical white matter of the left hemisphere and the splenium of the corpus callosum, consistent with PML. An analysis of the CSF using polymerase chain reaction (PCR) was positive for JCV [53]. PML in liver transplant patients has been found to be rare, with only eight cases of JCV reported post-transplantation up until 2019. Loyaga-Rendon et al. observed PML in a heart transplant recipient following rituximab therapy for antibody-mediated rejection [54]. A 48-year-old male underwent heart transplantation for dilated cardiomyopathy, and, at approximately four years post-transplantation, he developed acute cellular rejection (ACR), grade 3B, and C4d+ antibody-mediated rejection [54]. He was treated with pulse steroids, an increased daily cyclosporine dose to $275 \mathrm{mg}$, and MMF; due to persistent rejection, he was transitioned from cyclosporine to tacrolimus [54]. Years later, after five weeks of a rituximab therapy for ACR, he developed progressive motor and cognitive impairments and was diagnosed with PML. An MRI of the brain showed multiple confluent subcortical white matter lesions, and he tested positive for JCV by PCR of the CSF. He was treated with a reduction of his immunosuppressive medications, mirtazapine, intravenous immunoglobulin (IVIG), and plasmapheresis but did not survive [54]. Crowhurst et al. reported the development of PML in a 66-year-old male after lung transplantation for chronic hypersensitivity pneumonitis (Figure 2) [55]. At 19 months post-transplantation, he presented with nonspecific memory disturbances. An MRI revealed white matter abnormalities, and PML was confirmed by brain biopsy. Iatrogenic immunosuppression was halted, and the patient developed antibody-mediated rejection four months later [55]. The patient was later found neurologically stable on mirtazapine after the resumption of immunosuppression eight months following PML diagnosis [55]. Kishida et al. observed PML after an umbilical cord blood transplantation in a 37-year-old male with chemotherapy-related acute myelocytic leukemia (Figure 2) [56]. An MRI revealed multiple frontotemporal hyperintense white matter lesions on T2-FLAIR imaging, more prominent on the left side than on the right. A PCR of the CSF yielded positive results, showing 911,175 copies/mL [56]. Lajaunie et al. provided some evidence for the person-to-person transmission of PML by JCV in a clinical setting among three transplant patients (two, five, and eleven years post-transplantation), treated with combination therapies, including tacrolimus, mycophenolic acid belatacept, and steroids [57]. However, the confirmation of JCV sequences from viruses isolated from these patients was not performed [57]. The JCV normal sites of latency, including the kidney and bone marrow, may result in the virus reaction after immunosuppression for transplantation. PML is a rare complication following renal transplantation with an incidence of $0.027 \%$ in transplant recipients and is typically associated with high JCV viral loads in the CSF $[58,59]$. In addition, there have been only a few cases of nephropathy attributed to JCV. Viral shedding is common in immunocompetent individuals; however, the incidence of asymptomatic viruria is surprisingly not increased in renal allograft recipients $[60,61]$. Renal transplant patients with PML have significant JCV viruria, and studies have shown that both PML and JCV PyVAN can occur together [62]. The median time of PML development after transplant is approximately 30 months [63]. In a case study by Lin et al., a 63 -year-old female who developed lupus nephritis with end-stage renal disease (ESRD) received a living donor renal transplant. Six years post-transplant, she presented clinically with mild incontinence and a personality change characterized by slow responses and emotionless behavior. PML was suspected and later diagnosed via a stereotactic brain biopsy. A definitive diagnosis was made by immunohistochemistry (IHC) staining biopsy tissue for SV40 antibodies, which is typically used in the diagnosis of polyomavirus-associated diseases [58]. After diagnosis, the patients' immunosuppressive regimen was reduced accordingly [58]. JCV-associated PML in bone marrow transplants is not reviewed here. 


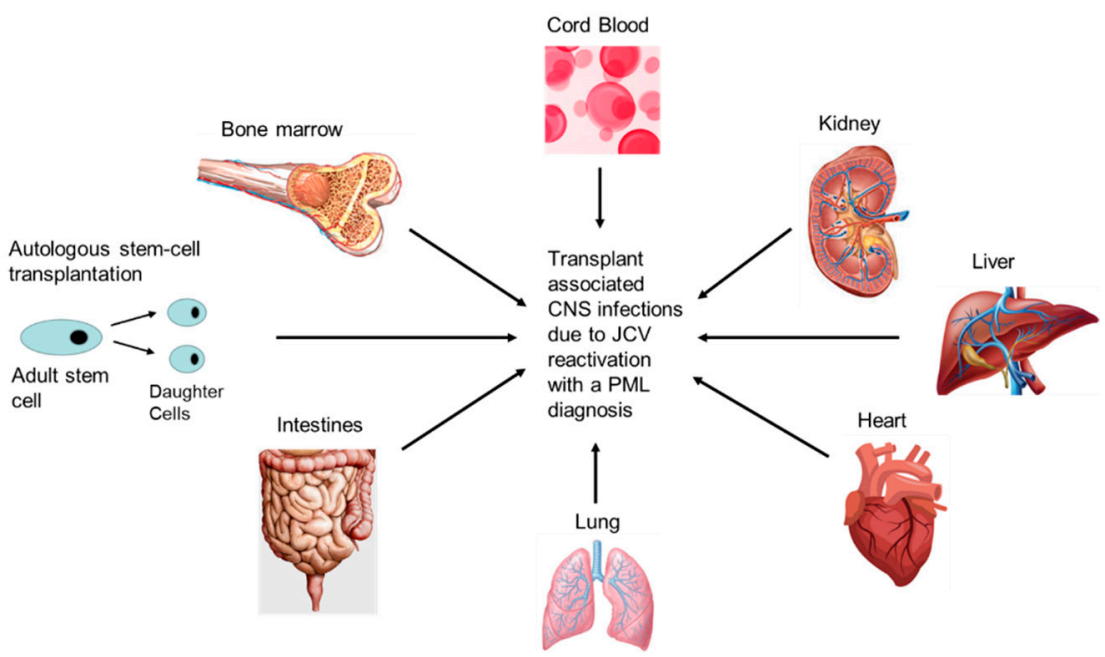

Figure 2. Transplantation and PML. Reported types of human transplantation (cord blood, kidney, liver, heart, lungs, intestines, autologous stem cells, and bone marrow) associated with a PML clinical diagnosis following iatrogenic immunosuppression. The image of the cord blood was obtained and modified from BioCord: "Researchers find new breakthrough in search for cure for blood cancers"; images of the kidney, liver, heart, and lungs were obtained and modified from Pearson Education 2012 for the image of alveolar organization that was modified (unpublished data); and images of the intestines and bone marrow were obtained and modified from National Geographic Kids: "Human Digestive System and from Health Visions, bloodless bone marrow transplants Narayana Health City respectively".

\subsection{Patients Receiving Biologics}

Most recently, PML has been observed among patients receiving immunomodulatory therapies that result in lymphocyte depletion, changes in lymphocytes function, or the prevention of lymphocyte transmigration. Fatal PML cases have been reported among patients using biologics (humanized monoclonal antibodies) for the treatment of multiple sclerosis (MS) and Crohn's disease. Natalizumab (TYSABRI ${ }^{\circledR}$ ) is a highly effective alpha4 integrin antagonist approved for the treatment of active relapsing-remitting multiple sclerosis [64]. Natalizumab binds to the $\alpha_{4}$ subunit of $\alpha_{4} \beta 1$ and $\alpha_{4} \beta_{7}$ integrins on lymphocytes and blocks binding to their endothelial receptor VCAM-1, preventing lymphocyte transmigration into the brain and thereby attenuating the inflammation associated with MS [65]. The net result is a reduction in T-cell immunesurveillance that can lead to the reactivation of JCV from latency and the develpment of PML. Rituximab (TRUXIMA ${ }^{\circledR}$,Genentech and Biogen Idec, South San Francisco, CA and Cambridge, MA, USA) is an anti-CD20 monoclonal antibody used in the treatment of many lymphoproliferative conditions and immune-mediated diseases, such as MS, non-Hodgkin's lymphoma, rheumatoid arthritis, autoimmune hematological disorders, myasthenia gravis, systemic lupus erythematosus, and B cell lymphoma. Rituximab is a chimeric monoclonal antibody that depletes B and pre-B cells that express CD20. It effects CD20+ B cells via antibody-dependent cytotoxicity, cell-mediated cytotoxicity, apoptosis, and the direct sensitization of cells to chemotherapy. The suppression of $\mathrm{B}$ cell functions effecting the humoral immune responses in controlling $\mathrm{JCV}$ can also lead to a reduction in B cell populations and functions that can lead to the reactivation and dissemination of JCV from latency and the develpment of PML. Efalizumab (RAPTIVA ${ }^{\circledR}$ ), a tumor necrosis factor alpha (TNF $\alpha$ ) inhibitor used for the treatment of plaque psoriasis, was withdrawn from the market in 2009 for causing PML [66]. The pathogenesis of TNF $\alpha$ inhibitors in PML is unclear; however, it has been proposed that $\mathrm{TNF} \alpha$ inhibitors may influence the frequency of JCPyV infection, viral load, and genotype selection, as well as interfere with lymphocyte recruitment and decrease interferon- $\gamma$ levels, thereby alleviating control of the antiviral state [67]. Among the biologics associated with 
the developemnt of PML, the highest risk is seen with natalizumab, followed by rituximab [67]. Dimethly furmurate (Tecfidera ${ }^{\mathrm{TM}}$ ), used to treat MS and psoriasis, are among the small molecules associated with PML risk [68]. Its therapeutic effect in MS is unknown but may activate the Nrf2 pathway in vivo that promotes the expression of products that protect against oxidative stress, which can inhibit the proliferation of lymphocytes and hematopoeietic stem cells [69]. Dimethyl fumarate has been shown to produce a significant sustained reduction in CD8 lymphocyte counts and, to a lesser extent, CD4 lymphocyte counts, which could lead to a level of immunsuppression that would contribute to the development of PML [70]. Belatacept (CTLA4-Ig), a CD28-B7 costimulation blocker and T-cell anergy inducer, was shown to produce rapidly fatal PML with JCV T-cell anergy in a renal transplant patient [71]. Therapies that induce T-cell anergy may lead to cases of PML that are difficult to manage with other clinical therapies. This autoimmune treatment-associated PML is due partly to the expanded use of biologics in the last 15 years. Individuals with lymphoproliferative disorders, AIDS, and immunomodulatory therapies comprise most of the PML cases, with an estimated worldwide incidence of two cases $/ 100,000$ persons, which will vary with the population [72].

\subsection{HIV Patients}

Largely, PML was a very rare disease until the mid-1980s; the increased incidence coincided with the HIV epidemic in the US [73]. The incidence of PML, classified as an AIDS-defining illness, was $2 \%-5 \%$ in HIV-infected patients; however, the introduction of antiretroviral therapy (ART) significantly reduced the incidence and mortality associated with PML disease [74]. HIV-associated PML is still problematic; however, ART therapy has made the disease more manageable in some HIV patients. Immune reconstitution with ART in HIV patients treated for PML disease may result in a fatal inflammatory reaction, IRIS [75].

\section{Treatment Strategies for PML}

Currently, no effective curative treatment for PML exists. Drugs such as cidofovir, cytarabine, and mefloquine have been used; however, these therapies are not specific, have no effect on virus replication, and have limited efficacy in crossing the BBB at the therapeutic level. In limited studies, these drugs were not shown to be clinically beneficial in PML treatment [76-79]. Immune restoration to restore anti-JCV T-cell responses has been found to be the most effective approach to PML treatment. Interleukin-2 (IL-2), used to stimulate $\mathrm{T}$ cells, and adoptive cytotoxic T-cell infusions for patients with T-cell deficiencies unrelated to HIV, have reportedly been successful in battling PML [80-82]. In a case study by Giacomni et al., they showed that treatment with maraviroc, a CCR5+ agonist, may selectively limit the trafficking of CCR5+ T-cell into the CNS, contributing to patient survival in both PML infection and PML-IRIS [83]. A recent study by Cortese et al. using pembrolizumab, which targets PD-1 (programmed cell death protein-1), a negative regulator of the immune response, may contribute to impaired viral clearance [84]. Their strategy involved blocking PD-1 on T cells with pembrolizumab to enhance the viral clearance, which could have an effect on the immune response to JCV. The results showed reductions in the JCV viral loads and an increase in CD4+ and CD8+ T-cell activity against the JCV, along with clinical improvement or stabilization in five of the eight patients who received pembrolizumab [84]. PML has a high fatality rate in most cases, and the current therapy is centered around prolonging patient survival. Treatment options for PML are limited, and the diagnosis frequently only occurs once symptoms are already severe [85]. Low CD4+ and CD8+ T-cell counts have been associated with more severe PML disease and the recovery of PML disease, respectively [86]. The use of polyomavirus JC-targeted cytotoxic T-cell therapy for PML in a hematopoietic cell transplantation recipient has shown promise, as it has led to an improvement in symptoms and clearance of JCV from the CSF [82]. 


\section{Discussion and Conclusions}

Transplant recipients who require immunosuppression, have HIV / AIDS, have malignancies, and/or receive routine infusions of biologics to treat autoimmune and inflammatory diseases, such as MS or Crohn's disease, should be monitored for abnormal neurological signs and symptoms associated with PML. Transplant patients who require iatrogenic immunosuppression are especially vulnerable to JCV reactivation in the brain, which may expose them to JCV lytic replication in the CNS, demyelination, and the life-threatening PML disease.

However, no curative treatment for JCV-induced PML exists to date. A PML diagnosis in transplant patients is often nonresponsive to existing therapies, and up to $50 \%$ of patients with PML will die without any treatment within the first few months of receiving a diagnosis. With the increased use of biologics, small molecules, antineoplastics, and immunosuppressants in clinical practice-many designed to impair cell-mediated immunity and neuroimmunosurveillance $[67,68]$ - the incidence of PML will increase in these patient populations. Therefore, it is essential to develop specific effective interventions, including antiviral strategies to prevent a JCV lytic infection upon reactivation in the CNS. This effort will require the development of therapies that are designed to cross the human BBB.

Author Contributions: D.J.A. conceptualized the study. D.J.A. and J.E.K.H. conceived and designed the study, D.J.A. performed the analysis, and D.J.A. and J.E.K.H. drafted the manuscript. All authors have read and agreed to the published version of the manuscript.

Funding: D.J.A. was supported by the Meharry Medical College Zika virus Research Startup Award. This research received no external funding.

Institutional Review Board Statement: Not applicable.

Informed Consent Statement: Not applicable.

Data Availability Statement: The study did not report any data.

Acknowledgments: The authors would like to thank Waldemar Popik for reviewing and reading the manuscript. In addition, the authors would like to thank the Meharry Office of Scientific Editing and Publications for the editorial services provided during manuscript preparation (NIH S21MD000104).

Conflicts of Interest: The authors declare that they have no competing interests.

Disclaimer: The funders did not participate in the design, preparation, data analysis, or decision to publish the manuscript.

\section{Abbreviations}

ACR Acute Cellular Rejection

AP-1 Activator protein 1

ART Antiretroviral Therapy

ASCT Autologous Stem Cell Transplant

BBB Blood-Brain Barrier

BKV BK polyomavirus

CCR5+ Biomarker on CD4+ T-cells

$\mathrm{C} / \mathrm{EBP} \beta \quad \mathrm{CCAAT} /$ enhancer-binding protein beta

CD4+ Cluster of Differentiation 4 positive

CD8+ Cluster of Differentiation 8 positive

CD20 Cluster of Differentiation 20 positive

CD28-B7 Cluster of Differentiation 28 and B7 positive

CSF Cerebral Spinal Fluid

CNS Central Nervous System

CTLA4-Ig Cytotoxic T-lymphocyte-associated protein 4-Immunoglobulin

CY-JCV Archetype CY Strain of JCV

Egr-1 Early Growth response protein 1 


$\begin{array}{ll}\text { EC } & \text { Endothelial cells } \\ \text { IL-2 } & \text { Interleukin-2 } \\ \text { IRIS } & \text { Immune Reconstitution inflammatory Syndrome } \\ \text { IVIG } & \text { Intravenous Immunoglobulin } \\ \text { JCV } & \text { JC polyomavirus } \\ \text { JCV PyVAN } & \text { JC polyomavirus associated nephropathy } \\ \text { MMF } & \text { Mycophenolate mofetil } \\ \text { MRI } & \text { Magnetic Resonance Imaging } \\ \text { MS } & \text { Multiple Sclerosis } \\ \text { NCRR } & \text { Non-Coding Regulatory Region } \\ \text { NF-kB } & \text { Nuclear factor kappa B } \\ \text { PCR } & \text { Polymerase Chain Reaction } \\ \text { PML } & \text { Progressive multifocal Leukoencephalopathy } \\ \text { Tat } & \text { Trans-Activator of Transcription } \\ \text { TNF } \alpha & \text { Tumor necrosis factor alpha } \\ \text { T2-FLAIR } & \text { T2-weighted-Fluid-Attenuated Inversion Recovery } \\ \text { VP1-3 } & \text { Viral Capsid Proteins 1-3 }\end{array}$

\section{References}

1. Zurhein, G.; Chou, S.M. Particles resembling papova viruses in human cerebral demyelinating disease. Science 1965, 148, 1477-1479. [CrossRef] [PubMed]

2. $\quad$ Padgett, B.L.; Walker, D.L.; ZuRhein, G.M.; Eckroade, R.J.; Dessel, B.H. Cultivation of papova-like virus from human brain with progressive multifocal leucoencephalopathy. Lancet 1971, 7712, 1257-1260. [CrossRef]

3. Gardner, S.D.; Field, A.M.; Coleman, D.V.; Hulme, B. New human papovavirus (B.K.) isolated from urine after renal transplantation. Lancet 1971, 1, 1253-1257. [CrossRef]

4. Kean, J.M.; Rao, S.; Wang, M.; Garcea, R.L. Seroepidemiology of human polyomaviruses. PLoS Pathog. 2009, 5, e1000363. [CrossRef]

5. Egli, A.; Infanti, L.; Dumoulin, A.; Buser, A.; Samaridis, J.; Stebler, C.; Gosert, R.; Hirsch, H.H. Prevalence of polyomavirus BK and JC infection and replication in 400 healthy blood donors. J. Infect. Dis. 2009, 199, 837-846. [CrossRef]

6. Major, E.O. Progressive multifocal leukoencephalopathy in patients on immunomodulatory therapies. Annu. Rev. Med. 2010, 61, 35-47. [CrossRef]

7. Brooks, B.R.; Walker, D.L. Progressive multifocal leukoencephalopathy. Neurol. Clin. 1984, 2, 299-313. [CrossRef]

8. Shishido-Hara, Y.; Yazawa, T.; Nagane, M.; Higuchi, K.; Abe-Suzuki, S.; Kurata, M.; Kitagawa, M.; Kamma, H.; Uchihara, T. JC Virus Inclusions in Progressive Multifocal Leukoencephalopathy: Scaffolding Promyelocytic Leukemia Nuclear Bodies Grow With Cell Cycle Transition Through an S-to-G2-Like State in Enlarging Oligodendrocyte Nuclei. J. Neuropathol. Exp. Neurol. 2014, 5, 442-453. [CrossRef]

9. Ferenczy, M.W.; Marshall, L.J.; Nelson, C.D.; Atwood, W.J.; Nath, A.; Khalili, K.; Major, E.O. Molecular biology, epidemiology, and pathogenesis of progressive multifocal leukoencephalopathy, the JC virus-induced demyelinating disease of the human brain. Clin. Microbiol. Rev. 2012, 3, 471-506. [CrossRef]

10. Hirsch, H.H.; Kardas, P.; Kranz, D.; Leboeuf, C. The human JC polyomavirus (JCPyV): Virological background and clinical implications. APMIS 2013, 8, 685-727. [CrossRef]

11. Pavlovic, D.; Patera, A.C.; Nyberg, F.; Gerber, M.; Liu, M. Progressive Multifocal Leukeoncephalopathy Consortium. Progressive multifocal leukoencephalopathy: Current treatment options and future perspectives. Ther. Adv. Neurol. Disord. 2015, 8, 255-273. [CrossRef] [PubMed]

12. Astrom, K.E.; Mancall, E.L.; Richardson, E.P., Jr. Progressive multifocal leuko-encephalopathy; a hitherto unrecognized complication of chronic lymphatic leukemia and Hodgkin's disease. Brain 1958, 8, 93-111.

13. Berger, J.R. The clinical features of PML. Cleve. Clin. J. Med. 2011, 78 (Suppl. 2), S8-S12. [CrossRef] [PubMed]

14. Padgett, B.L.; Walker, D.L. Virologic and serologic studies of progressive multifocal leukoencephalopathy. Prog. Clin. Biol. Res. 1983, 105, 107-117. [PubMed]

15. Walker, D.L.; Padgett, B.L. The epidemiology of human polyomaviruses. Prog. Clin. Biol. Res. 1983, 105, 99-106.

16. Bohra, C.; Sokol, L.; Dalia, S. Progressive Multifocal Leukoencephalopathy and Monoclonal Antibodies: A Review. Cancer Control 2017, 4, 1073274817729901. [CrossRef]

17. Casado, J.L.; Corral, I.; García, J.; Martinez-San Millán, J.; Navas, E.; Moreno, A.; Moreno, S. Continued declining incidence and improved survival of progressive multifocal leukoencephalopathy in HIV/AIDS patients in the current era. Eur. J. Clin. Microbiol. Infect. Dis. 2014, 2, 179-187. [CrossRef]

18. Berger, J.R.; Pall, L.; Lanska, D.; Whiteman, M. Progressive multifocal leukoencephalopathy in patients with HIV infection. J. Neurovirol. 1998, 4, 59-68. [CrossRef] 
19. Major, E.O.; Amemiya, K.; Tornatore, C.S.; Houff, S.A.; Berger, J.R. Pathogenesis and molecular biology of progressive multifocal leukoencephalopathy, the JC virus-induced demyelinating disease of the human brain. Clin. Microbiol. Rev. 1992, 5, 49-73. [CrossRef]

20. Feigenbaum, L.; Khalili, K.; Major, E.; Khoury, G. Regulation of the host range of human papovavirus JCV. Proc. Natl. Acad. Sci. USA 1987, 84, 3695-3698. [CrossRef]

21. White, M.K.; Gordon, J.; Berger, J.R.; Khalili, K. Animal Models for Progressive Multifocal Leukoencephalopathy. J. Cell Physiol. 2015, 12, 2869-2874. [CrossRef] [PubMed]

22. Cook, L. Polyomaviruses. Microbiol. Spectr. 2016, 4. [CrossRef] [PubMed]

23. Erickson, K.D.; Garcea, R.L. Viral replication centers and the DNA damage response in JC virus-infected cells. Virology 2019, 528, 198-206. [CrossRef] [PubMed]

24. Frisque, R.J.; Bream, G.L.; Cannella, M.T. Human polyomavirus JC virus genome. J. Virol. 1984, 51, 458-469. [CrossRef]

25. Perez-Liz, G.; Del Valle, L.; Gentilella, A.; Croul, S.; Khalili, K. Detection of JC virus DNA fragments but not proteins in normal brain tissue. Ann. Neurol. 2008, 64, 379-387. [CrossRef]

26. Coleman, D.V.; Wolfendale, M.R.; Daniel, R.A.; Dhanjal, N.K.; Gardner, S.D.; Gibson, P.E.; Field, A.M. A prospective study of human polyomavirus infection in pregnancy. J. Infect. Dis. 1980, 142, 1-8. [CrossRef]

27. Antonsson, A.; Green, A.C.; Mallitt, K.A.; O'Rourke, P.K.; Pawlita, M.; Waterboer, T.; Neale, R.E. Prevalence and stability of antibodies to the BK and JC polyomaviruses: A long-term longitudinal study of Australians. J. Gen. Virol. 2010, 91, 1849-1853. [CrossRef]

28. Kato, A.; Kitamura, T.; Takasaka, T.; Tominaga, T.; Ishikawa, A.; Zheng, H.Y.; Yogo, Y. Detection of the archetypal regulatory region of JC virus from the tonsil tissue of patients with tonsillitis and tonsilar hypertrophy. J. Neurovirol. 2004, 10, 244-249. [CrossRef]

29. Laghi, L.; Randolph, A.E.; Chauhan, D.P.; Marra, G.; Major, E.O.; Neel, J.V.; Boland, C.R. JC virus DNA is present in the mucosa of the human colon and in colorectal cancers. Proc. Natl. Acad. Sci. USA 1999, 96, 7484-7489. [CrossRef]

30. Ricciardiello, L.; Laghi, L.; Ramamirtham, P.; Chang, C.L.; Chang, D.K.; Randolph, A.E.; Boland, C.R. JC virus DNA sequences are frequently present in the human upper and lower gastrointestinal tract. Gastroenterology 2000, 119, 1228-1235. [CrossRef]

31. Randhawa, P.; Brennan, D.C. BK virus infection in transplant recipients: An overview and update. Am. J. Transplant. 2006, 9, 2000-2005. [CrossRef]

32. Randhawa, P.; Uhrmacher, J.; Pasculle, W.; Vats, A.; Shapiro, R.; Eghtsead, B.; Weck, K. A comparative study of BK and JC virus infections in organ transplant recipients. J. Med. Virol. 2005, 2, 238-243. [CrossRef] [PubMed]

33. Lopez, V.; Gutierrez, C.; Sola, E.; Garcia, I.; Burgos, D.; Cabello, M.; Leon, M.; Molina, M.G.; Hernandez, D. Does JC polyomavirus cause nephropathy in renal transplant patients? Transplant. Proc. 2010, 8, 2889-2891. [CrossRef] [PubMed]

34. Wiegley, N.; Walavalkar, V.; Aujla, H.; Chen, L.X.; Huang, Y.; Lee, B.K.; Jen, K.Y. Clinicopathologic Characteristics of JC Virus Nephropathy in Kidney Transplant Recipients. Transplantation 2020. [CrossRef] [PubMed]

35. Jensen, P.N.; Major, E.O. A classification scheme for human polyomavirus JCV variants based on the nucleotide sequence of the noncoding regulatory region. J. Neurovirol. 2001, 4, 280-287.

36. Markowitz, R.B.; Thompson, H.C.; Mueller, J.F.; Cohen, J.A.; Dynan, W.S. Incidence of BK virus and JC virus viruria in human immunodeficiency virus-infected and -uninfected subjects. J. Infect. Dis. 1993, 167, 13-20. [CrossRef]

37. Tan, C.S.; Dezube, B.J.; Bhargava, P.; Autissier, P.; Wüthrich, C.; Miller, J.; Koralnik, I.J. Detection of JC virus DNA and proteins in the bone marrow of HIV-positive and HIV-negative patients: Implications for viral latency and neurotropic transformation. J. Infect. Dis. 2009, 199, 881-888. [CrossRef] [PubMed]

38. Chapagain, M.L.; Nerurkar, V.R. Human polyomavirus JC [JCV] infection of human B lymphocytes: A possible mechanism for JCV transmigration across the blood-brain barrier. J. Infect. Dis. 2010, 202, 184-191. [CrossRef]

39. Delbue, S.; Branchetti, E.; Boldorini, R.; Vago, L.; Zerbi, P.; Veggiani, C.; Tremolada, S.; Ferrante, P. Presence and expression of JCV early gene large $\mathrm{T}$ antigen in the brains of immunocompromised and immunocompetent individuals. J. Med. Virol. 2008, 80, 2147-2152. [CrossRef]

40. Berger, J.R.; Houff, S.A.; Major, E.O. Monoclonal antibodies and progressive multifocal leukoencephalopathy. $m A b s$ 2009, 1 , 583-589. [CrossRef]

41. Ranganathan, P.N.; Khalili, K. The transcriptional enhancer element, kappa B, regulates promoter activity of the human neurotropic virus, JCV, in cells derived from the CNS. Nucleic Acids Res. 1993, 21, 1959-1964. [CrossRef] [PubMed]

42. Mayreddy, R.P.; Safak, M.; Razmara, M.; Zoltick, P.; Khalili, K. Transcription of the JC virus archetype late genome: Importance of the kappa B and the 23-base-pair motifs in late promoter activity in glial cells. J. Virol. 1996, 70, 2387-2393. [CrossRef]

43. Safak, M.; Gallia, G.L.; Khalili, K.A. 23-bp sequence element from human neurotrophic JC virus is responsive to NF-kappa B subunits. Virology 1999, 262, 178-189. [CrossRef] [PubMed]

44. Romagnoli, L.; Wollebo, H.S.; Deshmane, S.L.; Mukerjee, R.; Del Valle, L.; Safak, M.; White, M.K. Modulation of JC virus transcription by C/EBPb. Virus Res. 2009, 146, 97-106. [CrossRef] [PubMed]

45. Romagnoli, L.; Sariyer, I.K.; Tung, J.; Feliciano, M.; Sawaya, B.E.; Del Valle, L.; Ferrante, P.; Khalili, K.; Safak, M.; White, M.K. Early growth response-1 protein is induced by JC virus infection and binds and regulates the JC virus promoter. Virology 2008, 375, 331-341. [CrossRef] [PubMed] 
46. Tada, H.; Rappaport, J.; Lashgari, M.; Amini, S.; Wong-Staal, F.; Khalili, K. Trans-activation of the JC virus late promoter by the tat protein of type 1 human immunodeficiency virus in glial cells. Proc. Natl. Acad. Sci. USA 1990, 87, 3479-3483. [CrossRef]

47. Daniel, D.C.; Kinoshita, Y.; Khan, M.A.; Del Valle, L.; Khalili, K.; Rappaport, J.; Johnson, E.M. Internalization of exogenous human immunodeficiency virus-1 protein, Tat, by KG-1 oligodendroglioma cells followed by stimulation of DNA replication initiated at the JC virus origin. DNA Cell Biol. 2004, 23, 858-867. [CrossRef]

48. Dorries, K.; Vogel, E.; Gunther, S.; Czub, S. Infection of human polyomaviruses JC and BK in peripheral blood leukocytes from immunocompetent individuals. Virology 1994, 198, 59-70. [CrossRef]

49. Anand, P.; Hotan, G.C.; Vogel, A.; Venna, N.; Mateen, F.J. Progressive multifocal leukoencephalopathy: A 25-year retrospective cohort study. Neurol. Neuroimmunol. Neuroinflamm. 2019, 6, e618. [CrossRef]

50. Ishii, K.; Yamamoto, F.; Homma, S.; Okada, Y.; Nakamichi, K.; Saijo, M.; Tamaoka, A. Probable progressive multifocal leukoencephalopathy-immune reconstitution inflammatory syndrome with immunosuppressant dose reduction following lung transplantation: A case report and literature review. BMC Neurol. 2019, 1, 263. [CrossRef]

51. Bennett, K.M.; Storrar, N.; Johnson, P.; Fernandes, P.M. Progressive multifocal leukoencephalopathy (PML) following autologous peripheral blood stem cell transplantation for multiple myeloma. Clin. Case Rep. 2020, 6, 938-943. [CrossRef] [PubMed]

52. Lippa, A.M.; Ocwieja, K.E.; Iglesias, J.; Fawaz, R.; Elisofon, S.; Lee, C.; Sharma, T.S. Progressive multifocal leukoencephalopathy presenting with acute sensorineural hearing loss in an intestinal transplant recipient. Transpl. Infect. Dis. 2020, 4, e13304.

53. Ahmadinejad, Z.; Talebi, F.; Ayoobi, Y.N.; Ghiasvand, F. A 41-year-old female with progressive multifocal leukoencephalopathy after liver transplant. J. Neurovirol. 2019, 4, 605-607. [CrossRef] [PubMed]

54. Loyaga-Rendon, R.Y.; Taylor, D.O.; Koval, C.E. Progressive multifocal leukoencephalopathy in a heart transplant recipient following rituximab therapy for antibody-mediated rejection. Am. J. Transplant. 2013, 4, 1075-1079. [CrossRef] [PubMed]

55. Crowhurst, T.; Koszyca, B.; Holmes, M.; Holmes-Liew, C. Progressive multifocal leukoencephalopathy in a lung transplant recipient presenting with memory impairment: Case report and literature review. Transpl. Infect. Dis. 2020, 3, e13293. [CrossRef] [PubMed]

56. Kishida, S.; Tanaka, K. Mefloquine treatment in a patient suffering from progressive multifocal leukoencephalopathy after umbilical cord blood transplant. Intern. Med. 2010, 22, 2509-2513. [CrossRef]

57. Lajaunie, R.; Mengelle, C.; Kamar, N.; Del Bello, A. Possible patient to patient transmission of progressive multifocal leukoencephalopathy among kidney-transplant patients. Braz. J. Infect. Dis. 2020, 9, S1413-8670(20)30103-3. [CrossRef]

58. Marshall, L.J.; Major, E.O. Molecular regulation of JC virus tropism: Insights into potential therapeutic targets for progressive multifocal leukoencephalopathy. J. Neuroimmune Pharmacol. 2010, 3, 404-417. [CrossRef]

59. Lin, T.C.; Wu, M.Y.; Luh, H.T.; Lin, S.F.; Lin, C.M.; Tseng, Y.C.; Liu, Y.C.; Wu, M.S. Progressive multifocal leukoencephalopathy in a renal transplant patient. J. Neurovirol. 2019, 4, 612-615. [CrossRef]

60. Crowder, C.D.; Gyure, K.A.; Drachenberg, C.B.; Werner, J.; Morales, R.E.; Hirsch, H.H.; Ramos, E. Successful outcome of progressive multifocal leukoencephalopathy in a renal transplant patient. Am. J. Transplant. 2005, 5, 1151-1158. [CrossRef]

61. Rossi, A.; Delbue, S.; Mazziotti, R.; Valli, M.; Borghi, E.; Mancuso, R.; Calvo, M.G.; Ferrante, P. Presence, quantitation and characterization of JC virus in the urine of Italian immunocompetent subjects. J. Med. Virol. 2007, 4, 408-412. [CrossRef] [PubMed]

62. Kitamura, T.; Yogo, Y.; Kunitake, T.; Suzuki, K.; Tajima, A.; Kawabe, K. Effect of immunosuppression on the urinary excretion of BK and JC polyomaviruses in renal allograft recipients. Int. J. Urol. 1994, 1, 28-32. [CrossRef] [PubMed]

63. Mateen, F.J.; Muralidharan, R.; Carone, M.; van de Beek, D.; Harrison, D.M.; Aksamit, A.J.; Gould, M.S.; Clifford, D.B. Nath A Progressive multifocal leukoencephalopathy in transplant recipients. Ann. Neurol. 2011, 2, 305-322. [CrossRef] [PubMed]

64. Shitrit, D.; Nirit, L.; Shiran, S.I.; Izbicki, G.; Sofer, D.; Eldad, M.; Kramer, M.R. Progressive multifocal leukoencephalopathy in a lung transplant recipient. J. Heart Lung Transpl. 2003, 8, 946-950. [CrossRef]

65. Polman, C.H.; O'Connor, P.W.; Havrdova, E.; Hutchinson, M.; Kappos, L.; Miller, D.H.; Phillips, J.T.; Lublin, F.D.; Giovannoni, G.; Wajgt, A.; et al. AFFIRM Investigators. A randomized, placebo-controlled trial of natalizumab for relapsing multiple sclerosis. $N$. Engl. J. Med. 2006, 9, 899-910. [CrossRef] [PubMed]

66. Williamson, E.M.L.; Berger, J.R. Diagnosis and Treatment of Progressive Multifocal Leukoencephalopathy Associated with Multiple Sclerosis Therapies. Neurotherapeutics 2017, 4, 961-973. [CrossRef]

67. Jullien, D.; Prinz, J.C.; Langley, R.G.; Caro, I.; Dummer, W.; Joshi, A.; Dedrick, R.; Natta, P. T-cell modulation for the treatment of chronic plaque psoriasis with efalizumab (Raptiva): Mechanisms of action. Dermatology 2004, 4, 297-306. [CrossRef]

68. Multani, A.; Ho, D.Y. JC Polyomavirus Infection Potentiated by Biologics. Infect. Dis. Clin. N. Am. 2020, 2, 359-388. [CrossRef]

69. Khatri, B.O.; Garland, J.; Berger, J.; Kramer, J.; Sershon, L.; Olapo, T.; Sesing, J.; Dukic, M.; and Rehn, E. The effect of dimethyl fumarate (Tecfidera ${ }^{\mathrm{TM}}$ ) on lymphocyte counts: A potential contributor to progressive multifocal leukoencephalopathy risk. Mult. Scler. Relat. Disord. 2015, 4, 377-379. [CrossRef]

70. Hammer, A.; Waschbisch, A.; Kuhbandner, K.; Bayas, A.; Lee, D.; Duscha, A.; Haghikia, A.; Gold, R.; Ralf, A. The NRF2 pathway as potential biomarker for dimethyl fumarate treatment in multiple sclerosis. Ann. Clin. Transl. Neurol. 2018, 6, 668-676. [CrossRef]

71. Wu, Q.; Wang, Q.; Mao, G.; Dowling, C.A.; Lundy, S.K.; Yang, D.M. Dimethyl Fumarate Selectively Reduces Memory T Cells and Shifts the Balance between Th1/Th17 and Th2 in Multiple Sclerosis Patients. J. Immunol. 2017, 8, 3069-3080. [CrossRef] [PubMed] 
72. Dekeyser, M.; de Goër, M.G.; Hendel-Chavez, H.H.; Labeyrie, C.; Adams, D.; Nasser, G.A.; Gasnault, J.; Durrbach, A.; Taoufik, Y. Refractory T-Cell Anergy and Rapidly Fatal Progressive Multifocal Leukoencephalopathy After Prolonged CTLA4 Therapy. Open Forum Infect. Dis. 2017, 2, ofx100. [CrossRef] [PubMed]

73. Kartau, M.; Verkkoniemi-Ahola, A.; Paetau, A.; Palomäki, M.; Janes, R.; Ristola, M.; Lappalainen, M.; Anttila, V.J. The Incidence and Predisposing Factors of John Cunningham Virus-Induced Progressive Multifocal Leukoencephalopathy in Southern Finland: A Population-Based Study. Open Forum Infect. Dis. 2019, 2, ofz024. [CrossRef] [PubMed]

74. Holman, R.C.; Török, T.J.; Belay, E.D.; Janssen, R.S.; Schonberger, L.B. Progressive multifocal leukoencephalopathy in the United States, 1979-1994: Increased mortality associated with HIV infection. Neuroepidemiology 1998, 6, 303-309. [CrossRef]

75. Christensen, K.L.; Holman, R.C.; Hammett, T.A.; Belay, E.D.; Schonberger, L.B. Progressive multifocal leukoencephalopathy deaths in the USA, 1979-2005. Neuroepidemiology 2010, 3, 178-184. [CrossRef]

76. Post, M.J.; Thurnher, M.M.; Clifford, D.B.; Nath, A.; Gonzalez, R.G.; Gupta, R.K.; Post, K.K. CNS-immune reconstitution inflammatory syndrome in the setting of HIV infection, part 1: Overview and discussion of progressive multifocal leukoencephalopathyimmune reconstitution inflammatory syndrome and cryptococcal-immune reconstitution inflammatory syndrome. $A J N R A m$. $J$. Neuroradiol. 2013, 7, 1297-1307.

77. Clifford, D.B.; Nath, A.; Cinque, P.; Brew, B.J.; Zivadinov, R.; Gorelik, L.; Zhao, Z.; Duda, P. A study of mefloquine treatment for progressive multifocal leukoencephalopathy: Results and exploration of predictors of PML outcomes. J. Neurovirol. 2013, 4, 351-358. [CrossRef]

78. De Luca, A.; Ammassari, A.; Pezzotti, P.; Cinque, P.; Gasnault, J.; Berenguer, J.; Di Giambenedetto, S.; Cingolani, A.; Taoufik, Y.; Miralles, P.; et al. Gesida 9/99, IRINA, ACTG 363 Study Groups. Cidofovir in addition to antiretroviral treatment is not effective for AIDS-associated progressive multifocal leukoencephalopathy: A multicohort analysis. AIDS 2008, 14, 1759-1767. [CrossRef]

79. Hall, C.D.; Dafni, U.; Simpson, D.; Clifford, D.; Wetherill, P.E.; Cohen, B.; McArthur, J.; Hollander, H.; Yainnoutsos, C.; Major, E.; et al. Failure of cytarabine in progressive multifocal leukoencephalopathy associated with human immunodeficiency virus infection. AIDS Clinical Trials Group 243 Team. N. Engl. J. Med. 1998, 19, 1345-1351. [CrossRef]

80. Lindå, H.; von Heijne, A. Presymptomatic diagnosis with MRI and adequate treatment ameliorate the outcome after natalizumabassociated progressive multifocal leukoencephalopathy. Front. Neurol. 2013, 4, 11. [CrossRef]

81. Berger, J.R.; Levy, R.M.; Flomenhoft, D.; Dobbs, M. Predictive factors for prolonged survival in acquired immunodeficiency syndrome-associated progressive multifocal leukoencephalopathy. Ann. Neurol. 1998, 3, 341-349. [CrossRef] [PubMed]

82. Du Pasquier, R.A.; Kuroda, M.J.; Schmitz, J.E.; Zheng, Y.; Martin, K.; Peyerl, F.W.; Lifton, M.; Gorgone, D.; Autissier, D.; Letvin, N.L.; et al. Low frequency of cytotoxic T lymphocytes against the novel HLA-A*0201-restricted JC virus epitope VP1 (p36) in patients with proven or possible progressive multifocal leukoencephalopathy. J. Virol. 2003, 22, 11918-11926. [CrossRef] [PubMed]

83. Balduzzi, A.; Lucchini, G.; Hirsch, H.H.; Basso, S.; Cioni, M.; Rovelli, A.; Zincone, A.; Grimaldi, M.; Corti, P.; Bonanomi, S.; et al. Polyomavirus JC-targeted T-cell therapy for progressive multiple leukoencephalopathy in a hematopoietic cell transplantation recipient. Bone Marrow Transplant. 2011, 7, 987-992. [CrossRef] [PubMed]

84. Giacomini, P.S.; Rozenberg, A.; Metz, I.; Araujo, D.; Arbour, N.; Bar-Or, A. Maraviroc in Multiple Sclerosis-Associated PML-IRIS (MIMSAPI) Group. Maraviroc and JC virus-associated immune reconstitution inflammatory syndrome. N. Engl. J. Med. 2014, 5, 486-488. [CrossRef] [PubMed]

85. Cortese, I.; Muranski, P.; Enose-Akahata, Y.; Ha, S.K.; Smith, B.; Monaco, M.; Ryschkewitsch, C.; O'Major, E.; Ohayon, J.; Schindler, M.K.; et al. Pembrolizumab Treatment for Progressive Multifocal Leukoencephalopathy. N. Engl. J. Med. 2019, 17, 1597-1605. [CrossRef] [PubMed]

86. Tavazzi, E.; White, M.K.; Khalili, K. Progressive multifocal leukoencephalopathy: Clinical and molecular aspects. Rev. Med. Virol. 2012, 1, 18-32. [CrossRef] [PubMed] 